\author{
International Journal of Management Science and \\ Business Administration \\ Volume 5, Issue 6, September 2019, Pages 7-14 \\ DOI: $10.18775 /$ ijmsba.1849-5664-5419.2014.56.1001 \\ URL: http://dx.doi.org/10.18775/ijmsba.1849-5664-5419.2014.56.1001
}

\title{
The Influence of Website Service Quality on Customer Satisfaction Towards Online Shopping: The Mediating Role of Confirmation of Expectation
}

\author{
${ }^{1}$ Karl Markos Biswas, ${ }^{2}$ Mohammed Nusari, ${ }^{3}$ Abhijit Ghosh \\ ${ }^{1,2,3}$ Faculty of Business and Accountancy, Lincoln University College, Malaysia
}

\begin{abstract}
Researching on customer satisfaction is important because satisfied customers become loyal customers. Therefore, it is crucial to measure customer satisfaction towards online shopping because satisfied customers make repetitive purchasing and recommendations to others that will make profits of that particular e-commerce company. Customer satisfaction with online shopping can significantly be influenced by website service quality. Hence, earlier, many studies have been shown the relationship between website service quality and customer satisfaction. But still, limited literature has been focused on the mediating effects of the confirmation of customer expectation on the relationship between website service quality and customer satisfaction. Hence, this study aims to measure customer satisfaction based on the website service quality with confirmation of customer expectation. A total of 500 questionnaires were distributed to online customers who are working in the private banks in Bangladesh. Totally 342 questionnaires were used for further analysis out of 500, representing a response rate of 68.40\%. Hypothesis for direct effect was tested by regression analysis using Statistical Package for the Social Sciences (SPSS). The result of the study revealed that website service quality has a significant and positive relationship with confirmation of customers' expectations and in turn, their satisfaction level towards online shopping. Implications and directions for future research are also highlighted in this present study.
\end{abstract}

Keywords: Customer satisfaction, Online shopping, an E-commerce company, Website service quality, Bangladesh.

\section{Introduction}

After years of development of Bangladesh's online shopping market, there has been a noticeable increase in the number of online shopping websites in Bangladesh. It was published by Shah (2014) in 2014 that approximately 1.5 to 2 million people shopped online every year in Bangladesh. The emerging market for the online sectors was thus growing by $15 \%$ to $20 \%$. Moreover, it is estimated by Bangladesh Bank that around 1 million clients accessed mobile banking, and over 100 crore transactions were performed through mobile banking accounts. Apart from this, transactions worth about Tk. 14,700 crore have been annually performed through e-commerce (The Daily Star, 2015). Thus, it is said that Bangladesh's online shopping environment is maturing and offering improved levels of service nowadays.

The rapid growth of online shopping in Bangladesh focuses on the importance on the issue of identifying customer satisfaction which is considered as a factor to address how is website service quality in Bangladesh and whether customer expectations from these online shopping websites are confirmed or not. Previously, many authors have described online shopping customer satisfaction in the context of Bangladesh (Kasem \& Shamima, 2014; Rahman, Islam, Esha, Sultana, \& Chakravorty, 2018; Hossain, Jamil, \& Rahman, 2018; Suhan, 2015). But limited literature has discussed the effects of website service quality on the confirmation of customers' expectations and in turn, customer satisfaction. Even, the study describing the impact of confirmation of expectation from website service quality on the determination of customer satisfaction towards online shopping is not earlier conducted. Hence, this current study addressed this issue and investigated the mediating effect of the confirmation of the customer expectations on the relationship between website service quality and customer satisfaction towards online shopping in the context of Bangladesh. 


\section{Literature Review}

\subsection{Website Service Quality and Customer Satisfaction}

Online shopping websites are called a structured collection of information about products and services which are displayed in the form of text, graphics, and videos (Ghaffari and Ashkiki, 2015). The main aim of the online shopping website is to provide information to the customers. Hence, Ghaffari \& Ashkiki (2015) mentioned the quality of the information about the products and services that have been provided in the online shopping websites as the important indicators for determining customer satisfaction. Moreover, Hong, Zulkifli, Hamsani, \& Shuaib (2017) found a significant relationship between website quality and customer satisfaction. Therefore, low-quality websites can be an excellent reason for customer lost along with the profit reduction of the company. In this way, Kumar \& Velmurugan (2017) claimed that websites quality determines customers' purchasing decisions.

By proceeding with this process, customer satisfaction information can be known by understanding the online shopping website quality (Rasli et al., 2015). Because if customers feel that website quality is good, they tend to have higher satisfaction with online shopping. In contrary, if customers realize the poor quality of the online shopping website, they may be dissatisfied. Therefore, it is needed to know how website service quality impact on customers' feelings which eventually determine customers' satisfaction level towards online shopping. Several authors mentioned several website quality elements including information quality (Ghaffari \& Ashkiki, 2015; Vasić, Kilibarda, \& Kaurin, 2019; Ludin \& Cheng, 2014), system quality (Lin, Wu, \& Chang, 2011; Uzun \& Poturak, 2014) and service quality (Wang \& Le, 2015; Lin et al., 2011) that affect customer perception and in turn satisfaction level towards online shopping.

But previously, several authors focused on the website service quality to examine customer satisfaction (Augustie, 2014; Pawlasova \& Klezl, 2017; Zatalini \& Pamungkas, 2017). Because the electronic service quality can determine how effectively and efficiently a website can provide facilities in case of buying, selling and delivering goods and services to the online shopping customer (Ghaffari and Ashkiki, 2015). According to Parasuraman, Zeithaml, \& Berry (1988), service quality is the base of attaining information regarding customer satisfaction. Hence, according to the previous literature support, it can be said that website service quality can have a positive effect on customer satisfaction towards online shopping (Lin et al., 2011; Deyalage \& Kulathunga, 2019; Guo, Ling, \& Liu, 2012). Furthermore, Ghaffari \& Ashkiki (2015) discussed that a website could meet the expectations of users and customers that in turn, affect customer satisfaction. Consequently, website service quality may have a significant effect on the expectation confirmation, and the next section has been described regarding this.

\subsection{Website Service Quality and Confirmation Of Expectation}

A growing body of scholarly work has begun to examine the relationship between e-service quality and consumer expectations, primarily focusing on online shopping. The concept of electronic service quality is derived from the service quality construct suggested by (Parasuraman, Zeithaml, and Berry, 1994). Although there are no acceptable models and definitions of electronic service quality and its measurement, customer expectations confirmation regarding e-service quality is not even well described as those made in case of traditional service quality (Zeithaml, 1988). Because the service quality of the physical market can be measured by examining the customer's general expectations based on firm's performance (Nasser et al., 2015). On the other side, customer expectation in online shopping is different from the physical market. Because customer expectation confirmation depends on the online shopping website service quality, primarily how the website represents products and services with attractive information so that customers become interested to purchase (Nasser et al., 2015). Therefore, customer expectations from perceived service quality depend on confirmation or disconfirmation of the perceived service delivery, which consequently leads to the meeting, exceeding, or failure to customer satisfaction (Kim, 2012). Hence, it can be said that confirmation of customer expectation from website service quality can affect customer satisfaction. The next section will discuss this issue.

\subsection{Confirmation of Expectation and Customer Satisfaction}

Expectation-confirmation theory, suggested by Oliver (1980), indicated that satisfaction could be attained from disconfirmation and customer expectation of the products or services. This theory also describes that 'disconfirmation' has the strongest direct effect on satisfaction. Because confirmation of customer expectation happens when actual performance meets the expected standard. In contrary, negative disconfirmation can happen when actual performance fails to meet the expected standard. Consequently, the result of positive disconfirmation indicates actual performance 
exceeds the expected standard (Chen et al., 2009). Thus, Chen et al. (2009) investigated the effect of confirmation of customer expectation on customer satisfaction with internet shopping. Similarly, Kim (2012) also identified the relationship between expectation, confirmation, and satisfaction. Hozhabri, Raeesi, Nor, Salimianrizi, \& Tayebiniya (2014) additionally explained online shopping customer satisfaction with the confirmation of their expectation testing expectation-confirmation model in the context of Iran. Hence, based on the previous literature, it can be mentioned that there may have an important effect confirmation of customer expectation on examining their satisfaction level towards online shopping. Thus, this study explored it.

\subsection{Conceptual Framework}

In line with the theoretical evidence from the literature, this paper propagates that customer satisfaction research framework should include website service quality and confirmation of customer expectation. In this instance, the conceptual framework is depicted by adopting the expectation-confirmation model. Therefore, this paper proposes a research model to investigate customer satisfaction by assessing confirmation of customer expectation from website service quality. This can be illustrated as a diagram in Figure 1.

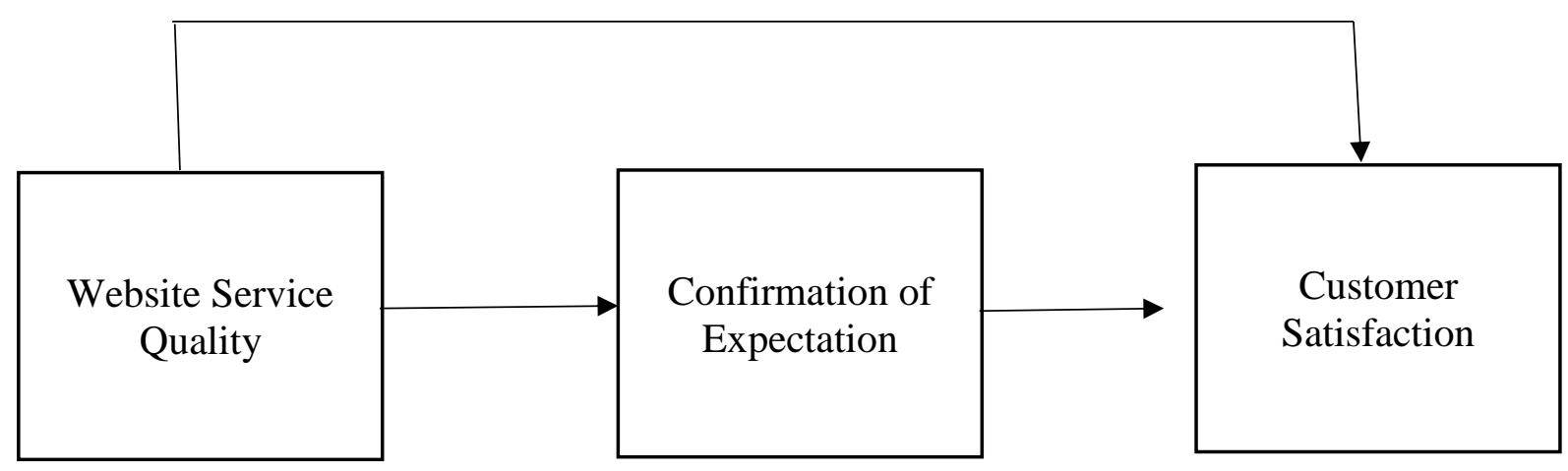

Figure 1: Conceptual Framework of Customer Satisfaction towards Online Shopping

\section{Hypotheses:}

H1: Website service quality will have a positive impact on customer satisfaction.

$\mathrm{H}$ 2: Website service quality will have a positive impact on the confirmation of expectation.

H3: confirmation of expectation will have a positive impact on customer satisfaction.

H4: Confirmation of expectation will mediate the relationship between website service quality and customer satisfaction.

\section{Methodology}

In this study, the quantitative method with a questionnaire survey has been used. Primary data was collected from a sample of 342 respondents in the Dhaka city of Bangladesh. The target population for the survey was a private banker in Dhaka city. Using the 5-point Likert scale, responses in the questionnaires (which were distributed among the target population using purposive and snowballing sampling method) were recorded with $1=$ strongly disagree, $2=$ Disagree, $3=$ Neutral, 4=Agree, and 5=Strongly Agree. Then, this study was used the statistical package for social sciences (SPSS) for the purpose of analyzing primary that was collected from the fieldwork. Values such as Cranach's alpha were determined by analysing reliability test. The questionnaire was divided into four sections. Section A collected the respondents' socio-demographic characteristics, including gender, age, marital status, household income, and education. The next part consists of three sections: section B (website service quality), section C (Confirmation of expectation), section D (customer satisfaction). The items of these above sections were taken from the previous studies of Lin \& Sun (2009); Pawlasova \& Klezl (2017); Al-jahwari, Khan, Kalbani, \& Khansouri (2018). The research methodology of this present study has been shortly showed in the below Table 1. 
Karl Markos Biswas, Mohammed Nusari, Abhijit Ghosh

The Influence of Website Service Quality on Customer Satisfaction Towards Online Shopping: The Mediating Role of Confirmation of Expectation

Table 1: Research Methodology

\begin{tabular}{|l|l|l|}
\hline 1. & Target population & Online shopping customers. \\
\hline 2. & Sampling frame & $\begin{array}{l}\text { Private bankers of the selected banks } \\
\text { (Prime bank, City bank, Brac bank, } \\
\text { and Asian development bank). }\end{array}$ \\
\hline 3. & Sampling technique & Judgmental and snowball sampling. \\
\hline 4. & Sample size & 342 \\
\hline 5. & Survey location & Dhaka city in Bangladesh. \\
\hline 6. & Analysis technique & $\begin{array}{l}\text { Descriptive analysis and regression } \\
\text { analysis. }\end{array}$ \\
\hline
\end{tabular}

\section{Result and Discussion}

The first part of questions relates to the personal information about the 342 online shopping customers, including the respondents' gender, age, marital status, household income, and education. This is shown in Table 2.

Table 2: Demographic Information

Profile of the Respondents in terms of Gender and Age

\begin{tabular}{llll}
\hline Variable & Descriptions & Frequency & Percentage \\
\hline Gender & Male & 141 & 41.20 \\
& Female & 201 & 58.80 \\
& Total & $\mathbf{3 4 2}$ & $\mathbf{1 0 0 . 0 0}$ \\
& & \\
Age & 25-29 years old & 62 & 18.10 \\
& 30-34 years old & 87 & 25.40 \\
& 35-39 years old & 54 & 15.80 \\
& 40-44 years old & 67 & 19.60 \\
& 45 years old and above & 72 & 21.10 \\
& Total & $\mathbf{1 0 0}$ & $\mathbf{1 0 0 . 0 0}$ \\
\hline
\end{tabular}

Profile of the Respondents (Marital Status, Household Income and Education)

\begin{tabular}{llll}
\hline Variable & Descriptions & Frequency & Percentage \\
\hline Marital Status & Single & 135 & 49.50 \\
& Married & 156 & 45.60 \\
& Divorcee/widow & 51 & 14.90 \\
& Total & $\mathbf{3 4 2}$ & $\mathbf{1 0 0 . 0 0}$ \\
Household Income & Less than USD 1000 & 122 & 35.70 \\
& USD 1001-2000 & 121 & 35.40 \\
& USD 2001-3000 & 57 & 16.70 \\
& USD 3001 and above & 42 & 12.30 \\
Education & Total & $\mathbf{1 0 0}$ & $\mathbf{1 0 0 . 0 0}$ \\
& Bachelor's Degree & & 23.10 \\
& Master's Degree & 79 & 46.50 \\
& Doctoral Degree & 159 & 9.10 \\
& Others & 31 & 21.30 \\
& Total & 73 & $\mathbf{1 0 0 . 0 0}$ \\
\hline
\end{tabular}


Karl Markos Biswas, Mohammed Nusari, Abhijit Ghosh

The Influence of Website Service Quality on Customer Satisfaction Towards Online Shopping: The Mediating Role of Confirmation of Expectation

From Table 3, it is noticeable that all the variables (website service quality, confirmation of expectation and customer satisfaction) of composite reliability and Cronbach's alpha are greater than 0.7 (Nunnally, 1978). Hence, it can be said that all the variables of this study are reliable.

Table 3: Reliability Test of Constructs

\begin{tabular}{|l|l|}
\hline Reliability Statistics & Cronbach's Alpha \\
\hline Website service quality & .720 \\
\hline Confirmation of expectation & 756 \\
\hline Customer Satisfaction & .878 \\
\hline
\end{tabular}

Table 4 shows that overall customer satisfaction and confirmation of expectation with website service quality range in between the mean value of 3.3392 and 3.7339. In relation to website service quality, majority of the respondents agreed and the range is "When I shop again, the same shopping website personnel or records would remember my related consumption habits" (mean value 3.6725 that is above 3 ) and "I trust that the shopping website can provide an appropriate service to me" (mean value 3.3392). Pertaining to confirmation of expectation, "My experience was better than that I expected while shopping from online stores" scored a mean value of 3.6637 and "Overall, most of my expectations from online shopping were confirmed" has a mean value of 3.3392. In the aspect of customer satisfaction towards online shopping, "I am satisfied with the online shopping security system" indicated the mean value of 3.7339 and "I feel comfortable in ordering products through online" attained a mean value of 3.4444.

Table 4: Descriptive Analysis

\begin{tabular}{|c|c|c|}
\hline Variables & Mean & Std. Deviation \\
\hline \multicolumn{3}{|l|}{ Website Service Quality } \\
\hline $\begin{array}{l}\text { When I shop again, the same shopping website personnel or } \\
\text { records would remember my related consumption habits. }\end{array}$ & 3.6725 & 1.31462 \\
\hline I am confident in buying products from the shopping website. & 3.4561 & 1.24533 \\
\hline I feel secure in buying products from the shopping website. & 3.4123 & 1.31634 \\
\hline $\begin{array}{l}\text { I trust that the shopping website can provide an appropriate } \\
\text { service to me. }\end{array}$ & 3.3392 & 1.28224 \\
\hline \multicolumn{3}{|l|}{ Confirmation of Expectation } \\
\hline $\begin{array}{l}\text { My experience was better than that I expected while shopping } \\
\text { from online stores. }\end{array}$ & 3.6637 & 1.38946 \\
\hline $\begin{array}{l}\text { The benefits provided by online websites were better than what I } \\
\text { expected. }\end{array}$ & 3.5409 & 1.21202 \\
\hline $\begin{array}{l}\text { The benefit provided from the online shopping in online stores } \\
\text { was better than traditional shopping from physical stores. }\end{array}$ & 3.3596 & 1.28693 \\
\hline $\begin{array}{l}\text { Overall, most of my expectations from online shopping were } \\
\text { confirmed. }\end{array}$ & 3.3392 & 1.27536 \\
\hline \multicolumn{3}{|l|}{ Customer Satisfaction } \\
\hline I am happy and prefer online shopping. & 3.6345 & 1.07397 \\
\hline Online shopping is easier and faster. & 3.5409 & 1.04577 \\
\hline I am satisfied with the online shopping security system. & 3.7339 & 1.11348 \\
\hline $\begin{array}{l}\text { Online shoppers take care of the timely delivery of the product, } \\
\text { assured package quality. }\end{array}$ & 3.4971 & 1.00073 \\
\hline I feel comfortable in ordering products through online. & 3.4444 & 1.13650 \\
\hline
\end{tabular}

Result of hypotheses testing 
Karl Markos Biswas, Mohammed Nusari, Abhijit Ghosh

The Influence of Website Service Quality on Customer Satisfaction Towards Online Shopping: The Mediating Role of Confirmation of Expectation

Table 5: Result of hypotheses testing

\begin{tabular}{|l|c|c|c|c|}
\hline \multicolumn{1}{|c|}{ Directions } & Hypothesized & $\boldsymbol{\beta}$ value & P-value & Result \\
\hline $\begin{array}{l}\text { Website service quality }- \text { customer } \\
\text { satisfaction }\end{array}$ & + & .213 & .000 that is $<0.05$ & Supported \\
\hline $\begin{array}{l}\text { Website service quality - confirmation of } \\
\text { expectation }\end{array}$ & + & .710 & .000 that is $<0.05$ & supported \\
\hline $\begin{array}{l}\text { Confirmation of expectation - customer } \\
\text { satisfaction }\end{array}$ & + & .178 & .001 that is $<0.05$ & Supported \\
\hline $\begin{array}{l}\text { Confirmation of expectation - website } \\
\text { service quality and customer satisfaction }\end{array}$ & + & .174 & .021 that is $<0.05$ & Supported \\
\hline
\end{tabular}

\section{Conclusion and Future Scope}

From the above results, we can conclude that website service quality significantly affects customer satisfaction in case of online shopping in Bangladesh. This result is consistent with the research conclusion of Lin \& Sun (2009) and Augustie (2014), who found that the quality of website services provided by an online store significantly affects customer satisfaction. In addition, from the outcome of this present study, it has been found that confirmation of customer expectation also has a positive effect on customer satisfaction. This finding is consistent with the research conclusion of Sarkar \& Khare (2018) and Chen, Huang, Hsu, Tseng, \& Lee (2010). Lastly, the current study showed a positive and significant mediating effect of confirmation of customer expectation on the relationship between website service quality and customer satisfaction towards online shopping in the context of Bangladesh.

The future study can be conducted by assessing online shopping customer re-purchase intention because of the confirmation of expectation from the website service quality. The present study was additionally limited to identifying other variables under website quality, including system quality and information quality, which also influence customer satisfaction. Hence, it is suggested that other factors affecting website quality should also be taken into consideration in further study.

\section{Recommendations}

In the light of the analysis and findings of this study, the following recommendations are considered necessary for the short, medium- and long-term implementations. The recommendations shall be outlined with respect to the objectives of the study. They are:

- There is need for Nigerian policy makers to pay more attention to the health sector and increased its yearly budgetary allocation to it. Nevertheless, the key to good results lies not in ordinarily increasing particular budgetary allocation but rather in implementing a public finance-system that, to the extent possible, links specific expenditure and revenue decisions and ensure the usage of the allocated fund as transparently as possible.

- Improved conditions of service for workers in the educational sector. This will help reduce the current brain drain in educational sector and more competent hands that will help improve productivity of the sector and the national economy at large.

- Government should strengthen its core functions by creating - strong macroeconomic policies to checkmate corrupt top government officials and politicians to embezzle or loot government fund in the name of providing infrastructural developments, jumbo projects and white elephant project that resulted in fund misappropriation which cannot translate to economic development in Nigeria.

- There should be vocational education that will produce practical oriented labour for entrepreneurship development. This should be enhanced by the government.

- Government should provide adequate -infrastructure services that support the full mobilization of all economic decision especially educational sector.

- There should be workable government policy on environmental sustainability and development that could promote conducive working environment that will bring about efficiency of labour as well as high level of productivity. 


\section{References}

- Al-jahwari, N. S. et al. (2018) 'Factors influencing customer satisfaction of online shopping in Oman- Youth perspective', Humanities \& Social Science Reviews, 6(2), pp. 64-73. Crossref

- Augustie, C. (2014) An analysis of factors influencing international online shopping: Indonesian perspective. Master dissertation, Universiti Utara Malaysia, Keday, Malaysia. Available at: http://etd.uum.edu.my/4214/2/s812444_abstract.pdf.

- Chen, Y.-Y. et al. (2010) 'Confirmation of expectations and satisfaction with the internet shopping: The role of internet self-efficacy', Computer and Information Science, 3(3), pp. 14-22. doi: 10.5539/cis.v3n3p14. Crossref

- Chen, Y. Y. et al. (2009) 'Confirmation of expectations and satisfaction with an on-line service: The role of internet self-efficacy', in International Conference on New Trends in Information and Service Science 2009 International Conference on New Trends in Information and Service Science Confirmation, pp. 880-885. Crossref

- Deyalage, P. A. and Kulathunga, D. (2019) 'Factors affecting online customer satisfaction: The Sri Lankan perspective', International Journal of Business and Management, 14(2), p. 99. Crossref

- Ghaffari, A. and Ashkiki, M. F. (2015) 'The impact on the quality of the website to buy online customers', Journal of Applied Environmental and Biological Sciences, 5(11S), pp. 516-526.

- Guo, X., Ling, K. C. and Liu, M. (2012) 'Evaluating factors influencing consumer satisfaction towards online shopping in China', Asian Social Science, 8(13), pp. 40-49.

- Hong, L. M. et al. (2017) 'The impact of website effectiveness towards online repurchase intention', Journal of Entrepreneurship and Business, 5(2), pp. 50-60. $\underline{\text { Crossref }}$

- Hossain, A., Jamil, A. Al and Rahman, M. (2018) 'Exploring the key factors influencing consumers' intention, satisfaction and loyalty towards online purchase in Bangladesh', International Journal of Economics and Financial Research, 4(7), pp. 214-225.

- Hozhabri, A. et al. (2014) 'Online re-purchase intention: Testing expectation confirmation model ECM on online shopping context in Iran', in 8th International Conference on e-Commerce in Developing Countries: With Focus on e-Trust, ECDC 2014, pp. 1-6. Crossref

- Internet Users Have Tk 14,700cr of Used Goods in Stock (2015) 'The Daily Star', 8 March. Available at: https://www.thedailystar.net/internet-users-have-tk-14-700cr-of-used-goods-in-stock-21873.

- Kasem, N. and Shamima, N. (2014) 'An assessment of the factors affecting the consumer satisfaction on online purchase in Dhaka City, Bangladesh', European Journal of Business and ManagementOnline), 6(32), pp. 2222-2839.

- Kim, D. J. (2012) 'An investigation of the effect of online consumer trust on expectation, satisfaction, and postexpectation', Information Systems and e-Business Management, 10(2), pp. 219-240. Crossref

- Kumar, M. and Velmurugan, R. (2017) 'Customer satisfaction towards online shopping in Coimbatore district', International Journal of Pure and Applied Mathematics, (15), pp. 41-49.

- Lin, C., Wu, H. and Chang, Y. (2011) 'The critical factors impact on online customer satisfaction Chun-Chun', Procedia Computer Science. Elsevier, 3(4), pp. 276-281. doi: 10.1016/j.procs.2010.12.047. Crossref

- Lin, G. T. R. and Sun, C. (2009) 'Factors influencing satisfaction and loyalty in online shopping: An integrated model', Online Information Review, 33(3), pp. 458-475. Crossref

- Ludin, I. H. B. H. and Cheng, B. L. (2014) 'Factors influencing customer satisfaction and E-Loyalty: Online shopping environment among the young adults', Management Dynamics in the Knowledge Economy, 2(3), pp. 462-471.

- Nasser, M. A.- et al. (2015) 'Analysis of e-service quality through online shopping', Research Journal of Business Management, 9(3), pp. 422-442. Crossref

- Nunnally, J. C. (1978) Psychometric theory. 2nd edn. New York: McGraw Hill Book Company.

- Oliver, R. L. (1980) 'A cognitive model of the antecedents and consequences of satisfaction decisions', Journal of Marketing Research, 17(4), pp. 460-469. Crossref

- Parasuraman, A., Zeithaml, V. A. and Berry, L. L. (1988) 'SERVQUAL: A multiple-item scale for measuring consumer perceptions of service quality', Journal of Retailing, 64(1), pp. 12-40.

- Parasuraman, A., Zeithaml, V. A. and Berry, L. L. (1994) 'Reassessment of expectations as a comparison standard in measuring service quality: Implications for further research', Journal of Marketing, 58(1), pp. 111-124. Crossref

- Pawlasova, P. and Klezl, V. (2017) 'Factors affecting generation y customers' satisfaction with online group-buying purchases in South Korea', Acta Universitatis Agriculturae et Silviculturae Mendelianae Brunensis, 65(6), pp. 20452054. $\underline{\text { Crossref }}$ 
- Rahman, M. A. et al. (2018) 'Consumer buying behavior towards online shopping: An empirical study on Dhaka city, Bangladesh', Cogent Business and Management. Cogent, 5(1), pp. 1-22. Crossref

- Rasli, S. et al. (2015) 'The impact of e-business website quality on customer satisfaction', (December), pp. 1-31.

- Sarkar, S. and Khare, A. (2018) 'Influence of expectation confirmation, network externalities, and flow on use of mobile shopping apps', International Journal of Human-Computer Interaction. Taylor \& Francis, 35(16), pp. 14491460. $\underline{\text { Crossref }}$

- Shah, J. (2014) 'Online shopping increases', Prothom Alo, 29 December. Available at: http://www.en.prothomalo.com/bangladesh/news/57411/Online-shopping-increases.

- Suhan, J. (2015) 'Acceptance of online shopping in Bangladesh: consumer's perspective', IOSR Journal of Business and Management (IOSR-JBM), 17(1), pp. 14-24. doi: 10.9790/487X-17121424.

- Uzun, H. and Poturak, M. (2014) 'Factors affecting online shopping behavior of consumers', European Journal of Social and Human Sciences, 3(3), pp. 163-170.

- Vasić, N., Kilibarda, M. and Kaurin, T. (2019) 'The influence of online shopping determinants on customer satisfaction in the Serbian market.', Journal of Theoretical and Applied Electronic Commerce Research, 14(2), pp. 70-89 $\underline{\text { Crossref }}$

- Wang, L. W. and Le, Q. L. (2015) 'Customer satisfaction towards online shopping at electronics shopping malls in Vietnam-A conceptual model to enhance business success through efficient websites and logistics services.', Journal of Stock \& Forex Trading, 5(1), pp. 1-10. Crossref

- Zatalini, M. A. and Pamungkas, T. N. (2017) 'Exploring the success factors of E-CRM implementation on B2c Ecommerce: Satisfaction and loyalty a conceptual framework', Jurnal Ilmiah Ekonomi Bisnis, 22(2), pp. 94-106. Available at: http://www.ejournal.gunadarma.ac.id/index.php/ekbis/article/view/1620.

- Zeithaml, V. A. (1988) 'Consumer perceptions of price, quality, and value: A Means-end model and synthesis of evidence', Journal of Marketing, 52(3), p. 2. Crossref 